\title{
Vermicompost, the story of organic gold: A review
}

\author{
Sujit Adhikary \\ Agriculture \& Ecological Research Unit, Biological Sciences Division, Indian Statistical Institute, Kolkata, India; \\ sujit@,isical.ac.in, drsujitadhikary@yahoo.com
}

Received 17 August 2012; revised 23 September 2012; accepted 11 October 2012

\begin{abstract}
Earthworm has caught imagination of philosophers like Pascal and Thoreau. Yet its role in the nutrition of agricultural fields has attracted attention of researchers worldwide only in recent decades. Waste management is considered as an integral part of a sustainable society, thereby necessitating diversion of biodegradable fractions of the societal waste from landfill into alternative management processes such as vermicomposting. Earthworms excreta (vermicast) is a nutritive organic fertilizer rich in humus, NPK, micronutrients, beneficial soil microbes; nitrogen-fixing, phosphate solubilizing bacteria, actinomycets and growth hormones auxins, gibberlins \& cytokinins. Both vermicompost \& its body liquid (vermiwash) are proven as both growth promoters \& protectors for crop plants. We discuss about the worms composting technology, its importance, use and some salient results obtained in the globe so far in this review update of vermicompost research.
\end{abstract}

Keywords: Vermicompost; Worms; Wastes;

Nutrients; Worm Biology; Importance

\section{INTRODUCTION}

A revolution is unfolding in vermiculture studies for vermicomposting of diverse organic wastes by waste eater earthworms into a nutritive "organic fertilizer" and using them for production of chemical free safe food in both quantity \& quality without recourse to agrochemicals. Heavy use of agrochemicals since the "green revolution" of the 1960s boosted food productivity at the cost of environment \& society. It killed the beneficial soil organisms \& destroyed their natural fertility, impaired the power of 'biological resistance' in crops making them more susceptible to pests $\&$ diseases. Chemically grown foods have adversely affected human health. The scientific community all over the world is desperately looking for an economically viable, socially safe \& environmen- tally sustainable alternative to the agrochemicals. Several farms in world especially in North America, Australia and Europe are going organic as the demand for "organic foods" are growing in society. In 1980, the US Board of Agriculture published a Report and Recommendations on Organic Farming based on case studies of 69 organic farmers in US and reported that over 90,000 to 100,000 farmers in US had already switched over to organic farming [1].

\section{GENERAL CHARACTERISTICS OF VERMICOMPOST AND VERMICULTURE}

Vermicompost is the excreta of earthworm, which are capable of improving soil health and nutrient status. Vermiculture is a process by which all types of biodegradable wastes such as farm wastes, kitchen wastes, market wastes, bio-wastes of agro based industries, livestock wastes etc. are converted while passing through the worm-gut to nutrient rich vermicompost. Vermi worms are used here act as biological agents to consume those wastes and to deposit excreta in the process called vermicompost.

\section{VERMICOMPOSTING}

Vermicomposting is a simple biotechnological process of composting, in which certain species of earthworms are used to enhance the process of waste conversion and produce a better product. Vermicomposting differs from composting in several ways [2]. It is a mesophilic process that utilizes microorganisms and earthworms that are active at $10^{\circ} \mathrm{C}$ to $32^{\circ} \mathrm{C}$ (not ambient temperature but temperature within the pile of moist organic material). The process is faster than composting; because the material passes through the earthworm gut, a significant but not fully understood transformation takes place, whereby the resulting earthworm castings (worm manure) are rich in microbial activity and plant growth regulators, and fortified with pest repellence attributes as well. In short, earthworms through a type of biological alchemy are capable of transforming garbage into "gold" [3,4]. 


\section{NUTRIENTS IN VERMICOMPOST}

Vermicompost is an excellent soil additive made up of digested compost. Worm castings are much higher in nutrients and microbial life and therefore, are considered as a higher value product (Table 1). Worm castings contain up to 5 times the plant available nutrients found in average potting soil mixes. Chemical analysis of the castings was conducted $[5,6]$ and found that it contains 5 times the available nitrogen, 7 times the available potash and 1.5 times more calcium than that found in $15 \mathrm{~cm}$ of good top soil. In addition, the nutrient life is up to 6 times more in comparison to the other types of potting mixes. It is reported that phosphorous while passage through gut of worms is converted to the plant available form [7]. Phosphorous is usually considered as a limiting element for plant growth. Therefore, any process that significantly increases phosphorous availability through plants and organic matter will be very important for agriculture. The average potting soil mixes that is found in the market are usually sterile and do not have a microbial population. The combination of nutrients and microbial organisms are essential for growing healthy and productive plants. Vermicompost not only adds microbial organisms and nutrients that have long lasting residual effects, it also modulates structure to the existing soil, increases water retention capacity. Vermicompost may also have significant effects on the soil physical properties. It was observed that addition of vermicompost @ $20 \mathrm{t} \cdot \mathrm{ha}^{-1}$ to an agricultural soil in two consecutive years significantly improved soil porosity and aggregate stability [8]. The number of large, elongated soil macro pores increased significantly after a single application of a dose of vermicompost equivalent to $200 \mathrm{~kg} \cdot \mathrm{ha}^{-1}$ of nitrogen to a cornfield [9]. Similarly, a significant decrease in soil bulk density and a significant increase in soil $\mathrm{pH}$ and total organic carbon after application of vermicompost in two consecutive growing seasons, at a rate equivalent to $60 \mathrm{~kg} \cdot \mathrm{ha}^{-1}$ of $\mathrm{N}$. Together these changes in soil properties improve the availability of air and water, thus encouraging seedling emergence and root growth [10].

Vermicompost contains an average of $1.5 \%-2.2 \% \mathrm{~N}$, $1.8 \%-2.2 \% \mathrm{P}$ and $1.0 \%-1.5 \% \mathrm{~K}$. The organic carbon is ranging from 9.15 to 17.98 and contains micronutrients

Table 1. A comparison of the chemical, microbiological properties of soil, vermicompost and manure are given.

\begin{tabular}{|c|c|c|c|}
\hline \multirow{2}{*}{ Parameters } & \multicolumn{3}{|c|}{ Nutrient available from } \\
\hline & Soil & Vermi-compost & Manure \\
\hline $\mathrm{pH}$ & $5.96 \pm 0.11$ & $8.09 \pm 0.09$ & $8.59 \pm 0.14$ \\
\hline Electrical conductivity $\left(\mathrm{mS} \cdot \mathrm{cm}^{-1}\right)$ & $0.33 \pm 0.04$ & $0.18 \pm 0.02$ & $3.05 \pm 0.08$ \\
\hline Moisture content $\left(\mathrm{g} \cdot \mathrm{kg}^{-1}\right)$ & $249 \pm 4$ & $535 \pm 3$ & $864 \pm 5$ \\
\hline Water holding capacity $\left(\mathrm{g} \cdot \mathrm{kg}^{-1}\right)$ & $361 \pm 4$ & $1103 \pm 13$ & ND \\
\hline DOC (mg $\cdot \mathrm{g}^{-1}$ dry matter $)$ & $0.13 \pm 0.03$ & $0.60 \pm 0.24$ & $15.4 \pm 7.91$ \\
\hline $\mathrm{DN}\left(\mathrm{mg} \cdot \mathrm{g}^{-1}\right.$ dry matter$)$ & $0.04 \pm 0.01$ & $0.07 \pm 0.03$ & $1.89 \pm 1.07$ \\
\hline Total C $\left(\mathrm{g} \cdot \mathrm{kg}^{-1}\right)$ & $31 \pm 1$ & $181 \pm 3$ & $299 \pm 6$ \\
\hline Total $\mathrm{N}\left(\mathrm{g} \cdot \mathrm{kg}^{-1}\right)$ & $3.0 \pm 0.3$ & $8.7 \pm 0.7$ & $14.2 \pm 1.5$ \\
\hline C-to-N ratio & 10.2 & 20.9 & 21.1 \\
\hline $\mathrm{NO}_{3}^{-}\left(\mathrm{mg} \cdot \mathrm{g}^{-1}\right.$ dry matter $)$ & $<0.1$ & $<0.1$ & $<0.1$ \\
\hline $\mathrm{NH}_{4}^{+}\left(\mathrm{mg} \cdot \mathrm{g}^{-1}\right.$ dry matter $)$ & $<0.1$ & $<0.1$ & $1.0 \pm 0.7$ \\
\hline $\mathrm{P}\left(\mathrm{mg} \cdot \mathrm{g}^{-1}\right.$ dry matter $)$ & $<0.1$ & $<0.1$ & $2.2 \pm 1.6$ \\
\hline $\mathrm{K}\left(\mathrm{mg} \cdot \mathrm{g}^{-1}\right.$ dry matter $)$ & $0.9 \pm 0.2$ & $1.3 \pm 0.1$ & $2.1 \pm 0.1$ \\
\hline $\mathrm{Ca}\left(\mathrm{mg} \cdot \mathrm{g}^{-1}\right.$ dry matter $)$ & $10.5 \pm 3.4$ & $26.3 \pm 2.2$ & $0.3 \pm 0.1$ \\
\hline $\mathrm{Na}\left(\mathrm{mg} \cdot \mathrm{g}^{-1}\right.$ dry matter $)$ & $0.05 \pm 0.05$ & $0.21 \pm 0.04$ & $0.42 \pm 0.02$ \\
\hline Background heterotrophic bacteria $\left(\log _{10} \mathrm{CFU} \cdot \mathrm{g}^{-1}\right)$ & 7.85 & 8.41 & 8.93 \\
\hline Escherichia coli $\mathrm{O} 157: \mathrm{H} 7\left(\log _{10} \mathrm{CFU} \cdot \mathrm{g}^{-1}\right)$ & 0.00 & 0.00 & 0.00 \\
\hline ND not determined. & & & \\
\hline
\end{tabular}

Values represent means $\pm \operatorname{SEM}(n=3)$. 
like Sodium (Na), Calcium (Ca), Zinc (Zn), Sulphur (S), Magnesium $(\mathrm{Mg})$ and Iron $(\mathrm{Fe})$. Chemical, microbiological properties of soil, vermicompost and organic manure are given (Table 1) with the following details: Soil (Eutric cambisol of the "Denbigh" series, $0-15 \mathrm{~cm}$ ) and earthworms (L. terrestris) were collected from a sheep-grazed pasture at Abergwyngregyn, North Wales, UK $\left(53^{\circ} 13.9^{\prime} \mathrm{N}, 4^{\circ} 0.9^{\prime} \mathrm{W}\right)$. Earthworm bedding material (digested paper pulp and green waste and earthworms (Dendrobaena veneta) were collected from commercial composting beds at the same site. Aged ( $>1$ month old) cattle manure was collected from a commercial farm in North Wales. After collection, all samples were stored in a climate-controlled room (Hemsec Ltd., Kirkby, UK) at $20^{\circ} \mathrm{C}, 70 \%$ relative humidity for the duration of the experimental period. This temperature was selected to reflect summertime soil and compost temperatures [11].

In another report [12] it is observed that the worm castings contain higher percentage (nearly two fold) of both macro and micronutrients than the garden compost (Table 2).

Earthworms consume various organic wastes and reduce the volume by $40 \%$ - $60 \%$. Each earthworm weighs about 0.5 to $0.6 \mathrm{~g}$, eats waste equivalent to its body weight and produces cast equivalent to about $50 \%$ of the waste it consumes in a day. The moisture content of castings ranges between $32 \%$ to $66 \%$ and the $\mathrm{pH}$ is around 7.0.

From various studies it is also, evident that vermincompost provides all nutrients in readily available form and enhances uptake of nutrients by plants. Soil available nitrogen increased significantly with increasing levels of vermicompost and highest nitrogen uptake was obtained

Table 2. Nutrient composition of vermicompost and garden compost are given.

\begin{tabular}{ccc}
\hline Nutrient element & Vermicompost (\%) & Garden compost (\%) \\
\hline Organic carbon & $9.8-13.4$ & 12.2 \\
Nitrogen & $0.51-1.61$ & 0.8 \\
Phosphorus & $0.19-1.02$ & 0.35 \\
Potassium & $0.15-0.73$ & 0.48 \\
Calcium & $1.18-7.61$ & 2.27 \\
Magnesium & $0.093-0.568$ & 0.57 \\
Sodium & $0.058-0.158$ & $<0.01$ \\
Zinc & $0.0042-0.110$ & 0.0012 \\
Copper & $0.0026-0.0048$ & 0.0017 \\
Iron & $0.2050-1.3313$ & 1.1690 \\
Manganese & $0.0105-0.2038$ & 0.0414 \\
\hline
\end{tabular}

at $50 \%$ of the recommended fertilizer rate plus $10 \mathrm{t} \cdot \mathrm{ha}^{-1}$ vermicompost. Similarly, the uptake of nitrogen $(\mathrm{N})$, phosphorus $(\mathrm{P})$, potassium $(\mathrm{K})$ and magnesium $(\mathrm{Mg})$ by rice (Oryza sativa) plant was highest when fertilizer was applied in combination with vermicompost [13]. The production of potato (Solanum tuberosum) by application of vermicompost in a reclaimed sodic soil in India was studied and observed that with good potato growth the sodicity (ESP) of the soil was also reduced from initial $96.74 \mathrm{~kg} / \mathrm{ha}$ to $73.68 \mathrm{~kg} / \mathrm{ha}$ in just about 12 weeks. The average available nitrogen $(\mathrm{N})$ content of the soil increased from initial $336.00 \mathrm{~kg} / \mathrm{ha}$ to $829.33 \mathrm{~kg} / \mathrm{ha}$ [14]. Vermicompost contains enzymes like amylase, lipase, cellulase and chitinase, which can break down the organic matter in the soil to release the nutrients and make it available to the plant roots [15].

\section{WORMS AND THEIR BIOLOGICAL FEATURES}

About 3000 species of earthworms are found worldwide. Out of which, approximately 384 species are reported to be found in India and their detail taxonomic studies have been done already [16]. Majority of earthworm species live in the soil, except some species like Pontodrilus burmudensis, which lives in estuarine water. Earthworms vary greatly in length [viz., Microscotex phosphoreus (Duges) is around $20 \mathrm{~mm}$ long while Drawida grandus (Bourus) may be one meter in length]. Earthworms are known to inhabit in diverse ecological niches. Besides, they are also found in organic materials like manures litter, compost, and hydrophilic environments near fresh and brackish water and also in snowy patches. Most of the earthworms are omnivorous; however, Agastrodrilus a carnivorous genus of earthworms from the Ivory Coast of Africa has been reported to feed upon other earthworms of the family Eudrilidae [17].

The most effective use of earthworms in organic waste management could be achieved when a detailed understanding of biology of all potentially useful species and their population dynamics, productivity and the life cycles of earthworms are known. Detail studies on Indian species [18] and tropical species [19] and knowledge about the reproductive strategies of earthworms have been done. Earthworms belong to the family Lumbricidae. Earthworms are hermaphrodites but self-fertilization is rarity. Cocoons or eggs are small varying according to earthworm species. Cocoon color changes with aging. At the age of 6 weeks, earthworm starts laying cocoons. In favorable food and weather conditions one pair of earthworms could produce approximately 100 cocoons in 6 weeks to 6 months [20]. Cocoons incubate roughly for about 3 - 5 weeks. Earthworms possess the ability to regenerate body segments, which are lost by accident or 
coercion. The doubling time i.e. the time taken by a given earthworm population to double in its number or biomass, specifically depends upon the earthworm species, type of food, climatic condition etc. For example, the mean doubling time of Lampito mauritii in different organic inputs ranges from 33.77 - 38.05 days while the value for Perionyx excavatus is $11.72-16.14$ days [20]. The adult worm might live for about two years. Fullgrown worms could be separated and dried in an oven to make "worm meal" which is a rich source of protein $(70 \%)$, which are often used as animal, poultry and fish feed. E. eugeniae is a manure worm, which has been extensively used in North America and Europe for vermin composting because of its voracious appetite, high rate of growth, and reproductive ability [21]. A few years back it was brought to India and it has been progressively increasing application in the vermicomposting of animal manure and other forms of biomass [22]. The other epigeic species used in large-scale vermin culture is E. foetida, which has high potential for bio-converting organic waste into vermin casts [23].

\section{MULTIPLICATION OF WORMS}

Earth worms can be multiplied in 1:1 mixture of cow dung and decaying leaves kept in a cement tank or wooden box or plastic bucket with proper drainage facilities. The nucleus culture of the worms needs to be introduced into the above mixture at the rate of 50 worms per $10 \mathrm{~kg}$ of organic wastes properly mulched with dried grass or straw in a wet gunny bag. The unit should be kept in shade. Sufficient moisture level should be maintained by occasional sprinkling of water. Within 1 - 2 months, the worms multiply 300 times, which can be used for large-scale vermin composting. Suitability of dry olive cake, municipal biosolids and cattle manure as substrates for Vermicomposting was evaluated and reported that larger weights of newly hatched earthworms were obtained in substrate containing dry olive cake [23]. In another study, maize straw was found to be the most suitable feed material compared to soybean (Glycine max) straw, wheat straw, chickpea (Cicer arientinum) straw and city refuse for the tropical epigeic earthworm, $\mathrm{Pe}$ rionyx excavatus [24].

\section{DIFFERENT SOURCES OF VERMICOMPOST}

Worms are used to convert organic waste into dark brown nutrient-rich humus. Worms leave behind while reducing the household wastes turn into a good source of manure for plants the excreta. In specific cases, worms could degrade specific pollutants and might allow community formation of useful microorganisms. Due to low cost nature of inputs, the price of vermicompost in the market is usually low in South Asian countries like India. Earthworms bio engineering principles which could potentially act as a substitute to thermophilic composting is becoming increasingly common and numerous studies have shown that increased plant growth and yield could be achieved when plants grown in the presence of vermicompost [25-28]. Vermicompost prepared from paper mill waste, application also showed better growth of Rehu fish (Labeo rohita, Hamilton) when compared with other commercially available organic manures [29].

\subsection{Vermicomposting from Household Wastes}

Following method could be adopted for making vermicompost from household wastes. A wooden box of 45 $\times 30 \times 45 \mathrm{~cm}$ or an earthen/plastic container with broad base and drainage holes should be used for this purpose. A plastic sheet with small holes should be placed at the bottom of the wooden box. $3 \mathrm{~cm}$ layer of soil and a $5 \mathrm{~cm}$ layer of coconut fiber for draining of excess moisture below it is kept inside the box. A thin layer of compost along with worms as inoculums was placed above it. About 250 worms are sufficient for the box. Vegetable wastes should be added in layers daily on top of the inoculums in daily basis. The top of the box should be covered with a piece of gunny bag to provide dim light inside the box. When the box is full, the box should be left undisturbed for a week. When the compost seems to be ready, the box should be kept in light for 2 - 3 hours so that the worms go down to the lowermost coconut fiber layer. The composted materials should be removed from the top of the box and gradually down and sieved for use in the urban or intensive horticultural and agricultural systems.

In Australia and New Zealand, vermiculture is being implemented from home worm bins to large scale composting of municipal biosolids and yard trimmings. A thriving industry is evolving to support these developments. Research continues in both the countries for further expand applications for earthworms and vermicomposting. At the household level, vermicomposting of food trimmings is becoming popular enough that a number of entrepreneurs have designed and are marketing home worm bins. Worm composting also is becoming more popular as an educational activity in schools [30].

\subsection{Vermicomposting of Farm Wastes}

Pits of sizes $2.5 \mathrm{~m} \times 1 \mathrm{~m} \times 0.3 \mathrm{~m}$ (length, breadth and depth) are taken in thatched sheds with sides left open. The bottom and sides of the pit are made hard by compacting with a wooden mallet. At the bottom of the pit a layer of coconut husk is spread with the concave side upward to ensure drainage of excess water and for proper 
aeration. The husk is moistened and above this, biowaste mixed with cow dung in the ratio of $8: 1$ is spread up to a height of $30 \mathrm{~cm}$ above the ground level and water is sprinkled daily. After the partial decomposition of wastes for 7 to 10 days, the worms are introduced @ 500 to 1000 in numbers per pit. The pit is covered with jute bags. Moisture is maintained at 40 to 50 per cent population density and a temperature of $20^{\circ} \mathrm{C}-30^{\circ} \mathrm{C}$ by sprinkling water over the bed. At higher temperature the worms is found to aestivate and at lower temperature, they will hibernate. When the compost is ready, it is removed from the pit along with the worms and heaped in shade with ample light. The worms will move to bottom of the heap. After one or two days, the compost from the top of the heap is removed. The undecomposed residues are put back to the pit with worms for further composting.

\subsection{Harvesting of Vermicompost}

Harvesting the compost means removing finished castings from the beds. The finished product is black or dark brown and is called crumbly worm compost. Harvesting the compost and adding fresh bedding, at least twice a year is necessary to keep the worms healthy. The compost can be harvested by spreading a sheet of plastic under a bright light or in the sun. The contents of the bed leaving the bedding materials are divided into a number of heaps on the sheet. The worms will crawl away from the light into the center of each heap and the worm compost can be brushed away on the outside by hand. The crawling worms will be collected for re-use.

\subsection{Precautions during the Process}

The following precautions should be taken during vermicomposting:

- The African species of earthworms, Eisenia fetida and Eudrilus eugenae are ideal for the preparation of vermicompost. Most Indian species are not suitable for the purpose.

- Only plant-based materials such as grass, leaves or vegetable peelings should be utilized in preparing vermicompost.

- Materials of animal origin such as eggshells, meat, bone, chicken droppings, etc. are not suitable for preparing vermicompost.

- Gliricidia loppings, tobacco leaves, onion, garlic, chilli etc. of kitchen wastes are not suitable for rearing earthworms.

- The earthworms should be protected against birds, termites, ants and rats.

- Adequate moisture should be maintained during the process. Either stagnant water or lack of moisture could kill the earthworms.
- After completion of the process, the vermicompost should be removed from the bed at regular intervals and replaced by fresh waste materials.

\section{BENEFICIAL ROLES OF VERMICOMPOST}

1) Red worm castings contain a high percentage of humus. Humus helps soil particles form into clusters, which create channels for the passage of air and improve its capacity to hold water. Presence of worms regenerate compacted soils and improves water penetration in such soils by over $50 \%$. [31-33]. US study indicate that 10,000 worms in a farm plot provides the same benefit as three farmers working 8 hours in shift all year round with 10 tons of manure applied in the plot [34]. Humic acid present in humus provides binding sites for the plant nutrients, such as calcium, iron, potassium, sulfur and phosphorus. These nutrients are stored in the humic acid in a form readily available to plants, and are released when the plants require them. The "humic acid" in vermicompost stimulates plant growth even in small amount [35]. The humic acid in humus are essential to plants in four basic ways: a) Enables plant to extract nutrients from soil; b) Help to dissolve unresolved minerals to make organic matter ready for plants to use; c) Stimulates root growth; and d) Helps plant to overcome stress. Presence of humus in soil even helps chemical fertilizers to work better [36].

2) Humus is believed to aid in the prevention of harmful plant pathogens, fungi, nematodes and bacteria [37]. Vermicompost has an ability to fight soil-borne plant diseases such as root rot. Humus also increases water permeability and water retention capacity, contributing to better plant health and more efficiently use in soil moisture. It is found that nitrogen concentrations are higher in vermicompost than in aerobic compost piles. There are other agronomic benefits of composts application, such as high levels of soil-borne disease suppression and removal of soil salinity. One study reported that mean root disease was reduced from $82 \%$ to $18 \%$ in tomato and from $98 \%$ to $26 \%$ in capsicum in soils amended with compost [38].

3) A worm casting (also known as worm cast or vermicast) is a biologically active mound containing thousands of bacteria, enzymes, and remnants of plant materials that were not digested by the worms. In fact, the bacterial population of a cast is much greater than the bacterial population of either ingested soil, or the worm's gut. Microbial activity of beneficial microorganisms in worm castings is ten to twenty times higher than that of in the soil and other organic matter [39]. Among beneficial soil microbes stimulated by earth worms are "nitrogen-fixing \& phosphate solubilizing bacteria", the "ac- 
tinomycetes" \& "mycorrhizal fungi". Studies found that the total bacterial count was more than 10/gm of vermincompost. It included Actinomycetes, Azotobacter, Rhizobium, Nitrobacter \& Phosphate solubilizing Bacteria ranges from 102 - 106 per gm of vermicompost [40].

4) Castings contain slow released nutrients that are readily available to plants. Castings contain the plant nutrients that are encased in mucus membranes that are secreted by the earthworms. They dissolve slowly rather than allowing immediate nutrient leaching. The product has excellent soil structure, porosity, and aeration and water retention capabilities. Castings can hold $2-3$ times more water than their weight in soil. Worm castings do not burn root systems. The product can insulate plant roots from extreme temperatures, reduce erosion and control weeds. It is odorless and consists of $100 \%$ recycled materials. Vermicompost also has very "high porosity", "aeration", "drainage" and "water holding capacity" than the conventional compost and this again due to humus contents [40].

5) The activity of the worm gut is like a miniature composting tube that mixes conditions and inoculates the residues [41]. Moisture, $\mathrm{pH}$, and microbial populations in the gut are favorably maintained for a synergistic relationship, and then a terrific byproduct [42]. They swallow large amount of soil with organics (microbes, plant \& animal debris) everyday, grind them in their gizzard and digest them in their intestine with aid of enzymes. Only 5 - 10 percent of the chemically digested and ingested material is absorbed into the body and the rest is excreted out in the form of fine mucus coated granular aggregates called "vermicastings" which are rich in NKP (nitrates, phosphates and potash), micronutrients and beneficial soil microbes [43].

6) Worm castings are the best imaginable potting soil for greenhouses or houseplants, as well as gardening and farming. It will not burn even the most delicate plants and all nutrients are water soluble, making it an immediate plant food. Earthworm castings, in addition to their use as a potting soil, can be used as a planting soil for trees, vegetables, shrubs, and flowers. They may be used as mulch so that the materials leach directly into the ground when watered.

7) Plant Growth Regulating Activity: Some studies speculated that the growth responses of plants from vermicompost appeared more like "hormone induced activiity" associated with the high levels of nutrients, humic acids and humates in vermicompost $[25,44]$. Researches show that vermicompost use further stimulates plant growth even when plants are already receiving "optimal nutrition". It consistently improved seed germination, enhanced seedling growth and development, and increased plant productivity significantly much more than would be possible from the mere conversion of mineral nutrients into plant available forms. Some studies have also reported that vermicompost contained growth promoting hormone "auxins", "cytokinins" and flowering hormone "gibberellins" secreted by earth-worms $[40,45$, 46]. Growth promoting activity of vermicompost was tested [12] using a plant bioassay method. The plemule length of maize (Zea mays) seedling was measured $48 \mathrm{~h}$ after soaking in vermicompost water and in normal water. The marked difference in plemule length of maize seedlings indicated that plant growth promoting hormones are present in vermicompost (Table 3). Further, vermicompost makes plants grow fast and strong. Nematodes and diseases will not ruin gardens or plants if the soil is rich enough for them to grow fast. It is the weak plant in poor soil that is destroyed by nematodes and diseases [47].

Positive effects of vermicompost include stimulated seed germination in several plant species such as green gram [48], tomato plants [49,50], petunia [51] and pine trees [52]. Vermicompost also has a positive effect on vegetative growth, stimulating shoot and root development [53]. The effects include alterations in seedling morphology such as increased leaf area and root branching [54] and also has been shown to stimulate plant flowering, increasing the number and biomass of the flowers produced $[51,55]$ as well as increasing fruit yield $[26,27,49,56]$.

8) Ability to Develop Biological Resistance in Plants: Vermicompost contains some antibiotics and actinomycetes that help in increasing the "power of biological resistance" among the crop plants against pest and diseases. Spray of chemical pesticides was significantly reduced by over $75 \%$ where earthworms and vermicompost were used in agriculture [40,57].

9) Ability to Minimize Pests Attack: There seems to be strong evidence that worm castings sometimes repel hard-bodied pests [58,59]. Studies reported statistically significant decrease in arthropods (aphids, buds, mealy bug, and spider mite) populations, and subsequent reduction in plant damage, in tomato, pepper, and cabbage trials with $20 \%$ and $40 \%$ vermicompost additions [60]. Munroe doing commercial vermicomposting in California, US, claims that his product repels many different insect pests. His explanation is that this is due to production of enzymes "chitinase" by worms which breaks down the chitin in the insect's exoskeleton [61]. As regards the effects of vermicompost on insect pests and mites, field studies have shown that the addition of vermicompost to soil significantly reduces the incidence of

Table 3. Plemule length of maize seedlings.

\begin{tabular}{rcc}
\hline Treatment & Initial length $(\mathrm{cm})$ & Final length $(\mathrm{cm})$ \\
\hline Tank water & 16.5 & 16.6 \\
Vermi-wash & 17.6 & 18.6 \\
\hline
\end{tabular}


the psyllids Heteropsylla cubana [62] the sucking insect Aproaerema modicella [63], jassids, aphids, beetles, and spider mites [64]. Studies also reported considerable suppression of root knot nematode (Meloidogyne incognita) and drastic suppression of spotted spider mites (Tetranychus spp.) and aphid (Myzus persicae) in tomato plants after application of vermicompost teas (vermiwash liquid) [65].

10) Ability to Suppress Plant Disease: Studies reported that vermicompost application suppressed 20\% - 40\% infection of insect pests i.e. aphids (Myzus persicae), mearly bugs (Pseudococcus spp.) and cabbage white caterpillars (Peiris brassicae) on pepper (Capiscum annuum), cabbage (Brassica oleracea) and tomato (Lycopersicum esculentum) [66]. Studies have also found that use of vermicompost in crops inhibited the soil born fungal diseases. They also found significant suppression of plant-parasitic nematodes in field trials with pepper, tomatoes, strawberries and grapes [60]. The scientific explanation behind this concept is that high levels of agronomic beneficial microbial population in vermincompost protects plants by outcompeting plant pathogens for available food resources i.e. by starving them and also by blocking their excess to plant roots by occupying all the available sites. They also reported the disease suppressing effects by the applications of vermicompost, on attacks by fungus Pythium on cucumber, Rhizoctonia on radishes in the greenhouse, by Verticillium on strawberries and by Phomposis and Sphaerotheca fulginae on grapes in the field. In all these experiments vermicompost applications suppressed the incidence of the disease significantly. They also found that the ability of pathogen suppression disappeared when the vermicompost was sterilized, convincingly indicating that the biological mechanism of disease suppression involved was microbial antagonism. Vermicompost has also been found to have a wide range of indirect effects on plant growth such as the mitigation or suppression of plant diseases. Suppression of plant diseases has been extensively investigated in other organic amendments such as manure and compost [67-69]. Likewise, some studies have shown that vermicompost can suppress a wide range of microbial diseases, insect pests and plant parasitic nematodes. As regards the suppression of fungal diseases, [70] it was observed that the addition of vermicompost extracts to three ornamental plant species significantly reduced sporulation of the pathogen Phytophthora cryptogea. Similarly, aqueous extracts of vermicompost were capable of reducing the growth of pathogenic fungi such as Botrytis cinerea, Sclerotinia sclerotiorum, Corticium rolfsii, Rhizoctonia solani and Fusarium oxysporum [71]. The addition of solid vermicompost to tomato seeds significantly reduced infection caused by Fusarium lycopersici [72] and Phytophthora nicotianae [73]. Never- theless, they did not find any significant suppressive effects of a sewage sludge vermicompost on Phytophthora nicotianae, in comparison with peat. Edward et al., observed that the suppressive effect exerted by several types of vermicompost on several plant pathogens such as Pythium, Rhizoctonia, Verticillium, and Plectosporium, disappeared after sterilization of the vermicompost, and concluded that disease suppression may be related to the presence of biological suppressive agents in vermicompost [74].

11) Vermimeal Production: With the increasing demand for animal feed protein bolstered by the continuing growth in human population and food source, the production of vermimeal may be considered as the most economically feasible application of vermiculture. According to Kale, vermiculture has bright prospects in the animal feed industry [75]. Vermimeal or earthworm meal is a feed preparation consisting of processed earthworm biomass. It is a rich source of animal protein as well as essential amino acids, fats, vitamins, and minerals for livestock, birds and fish. About $5.5 \mathrm{~kg}$ of fresh ANC biomass (18\% dry matter) is needed to produce $1 \mathrm{~kg}$ of vermimeal. It can be packed in plastic bags and stored in a cool dry place out of direct sun for up to 3 months. Proximate analysis of an ANC vermimeal in dry and pulverized form revealed the following composition; $68 \%$ crude protein, $9.57 \%$ fat, $11.05 \%$ nitrogen-free extract, and $9.07 \%$ ash [76]. Numerous studies on different livestock animals, birds and fishes have shown excellent results of feeding the animals with vermimeal or earthworm meal [77]. This is not surprising, considering that earthworms are a natural source of nutrition for birds and other animals in the wild.

\section{APPLICATION IN CROP PLANTS}

There have been several reports that earthworms and its vermicompost can induce excellent plant growth and enhance crop production.

\subsection{Cereal Crops}

Glasshouse studies made at CSIRO Australia found that the earthworms (Aporrectodea trapezoids) increased growth of wheat crops (Triticum aestivum) by $39 \%$, grain yield by $35 \%$, lifted protein value of the grain by $12 \%$ \& resisted crop diseases as compared to the control. The plants were grown in a "red-brown earth" with poor nutritional status and $60 \%$ moisture. There were about 460 worms per $\mathrm{m}^{-2}$ [78]. They also reported that in Parana, Brazil invasion of earthworms significantly altered soil structure and water holding capacity. The grain yields of wheat and soybean was increased by $47 \%$ and $51 \%$, respectively [79]. Some studies were made on the impact of vermicompost and garden soil in different proportion 
on wheat crops in India. It was found that when the garden soil and vermicompost were mixed in 1:2 proportions, the growth was about $72 \%-76 \%$ while in pure vermicompost, the growth increased by $82 \%-89 \%$ [80]. Another study reported that earthworms \& its vermicast improve the growth and yield of wheat by more than 40\% [81] (Palanisamy, 1996). Other studies also reported better yield and growth in wheat crops applied with vermicompost in soil [82-84]. Studies made on the agronomic impacts of vermicompost on rice crops (Oryza sativa) reported greater population of nitrogen fixers, actinomycetes and mycorrhizal fungi inducing better nutrient uptake by crops and better growth [85]. Another study was made on the impact of vermicompost on ricelegume cropping system in India. Integrated application of vermicompost, chemical fertilizer and biofertilizers (Azospirillum \& phosphobacteria) increased rice yield by $15.9 \%$ over chemical fertilizer used alone. The integrated application of $50 \%$ vermicompost, $50 \%$ chemical fertilizer and biofertilizers recorded a grain yield of 6.25 and 0.51 ton/ha in the rice and legume respectively. These yields were $12.2 \%$ and $19.9 \%$ higher over those obtained with 100\% chemical fertilizer when used alone [86]. Studies made in the Philippines also reported good response of upland rice crops grown on vermicompost [87].

\subsection{Fruit Crops}

Study found that worm waste (vermicompost) boosted grape yield by two-fold as compared to chemical fertilizers. Treated vines with vermicompost produced $23 \%$ more grapes due to $18 \%$ increase in bunch numbers. The yield in grapes was worth additional value [88]. Farmer in Sangli district of Maharashtra, India, grew grapes on "eroded wastelands" and applied vermicasting @ 5 tons/ha. The grape harvest was normal with improvement in quality, taste and shelf life. Soil analysis showed that within one year $\mathrm{pH}$ came down from 8.3 to 6.9 and the value of potash increased from $62.5 \mathrm{~kg} / \mathrm{ha}$ to $800 \mathrm{~kg} / \mathrm{ha}$. There was also marked improvement in the nutritional quality of the grape fruits [89]. Study was made on the impacts of vermicompost and inorganic (chemical) fertilizers on strawberries (Fragaria ananasa) when applied separately and in combination. Vermicompost was applied @ 10 tons/ha while the inorganic fertilizers (nitrogen, phosphorus, potassium)@85(N):155 (P):125 (K) $\mathrm{kg} /$ ha. Significantly, the yield of marketable strawberries and the weight of the largest fruit was $35 \%$ greater on plants grown on vermicompost as compared to inorganic fertilizers in 220 days after transplanting. Also there were $36 \%$ more "runners" and $40 \%$ more "flowers" on plants grown on vermicompost. Also, farm soils applied with vermicompost had significantly greater "microbial bio- mass" than the one applied with inorganic fertilizers [32]. Studies also reported that vermicompost increased the yield of strawberries by $32.7 \%$ and drastically reduced the incidence of physiological disorders like albinism $(16.1 \% \rightarrow 4.5 \%)$, fruit malformations $(11.5 \% \rightarrow 4 \%)$, grey mould $(10.4 \% \rightarrow 2.1 \%)$ and diseases like botrytis rot. By suppressing the nutrient related disorders, vermincompost use increased the yield and quality of marketable strawberry fruits up to $58.6 \%$ [56]. Impact of vermicompost on cherries found that it increased yield of "cherries" for three (3) years after "single application" inferring that the use of vermicompost in soil builds up fertility and restore its vitality for long time and its further use can be reduced to a minimum after some years of application in farms. At the first harvest, trees with vermicompost yielded an additional \$63.92 and \$70.42 per tree and after three harvests profits per tree were $\$ 110.73$ and \$142.21, respectively [90].

\subsection{Vegetable Crops}

Studies on the production of important vegetable crops like tomato (Lycopersicum esculentus), eggplant (Solanum melangona) and okra (Abelmoschus esculentus) have yielded very good results [89,91-93]. Another study was made on the growth impact of earthworms (with feed materials), vermicompost, cow dung compost and chemical fertilizers on okra (Abelmoschus esculentus). Worms and vermicompost promoted excellent growth in the vegetable crop with more flowers and fruits development. But the most significant observation was drastically less incidence of "Yellow Vein Mosaic", "Color Rot" and "Powdery Mildew" diseases in worm and vermicompost applied plants [94]. Study was made on the production of potato (Solanum tuberosum) by application of vermicompost in a reclaimed sodic soil in India. The overall productivity of potato was significantly high (21.41 tons/ha) on vermicompost applied @ 6 tons/ha as compared to control which was 04.36 tons/ha. The sodicity of the soil was also reduced and nitrogen $(\mathrm{N})$ contents increased significantly [14]. Study was made on the growth impacts of organic manure (containing earthworm vermicast) on garden pea (Pisum sativum) and compared with chemical fertilizers. Vermicast produced higher green pod plants, higher green grain weight per plant, higher percentage of protein content and carbohydrates and higher green pod yield $(24.8 \%$ - $91 \%)$ as compared to chemical fertilizer [95]. Studies made on the effects of vermicompost \& chemical fertilizer on the hyacinth beans (Lablab purpureas) it was found that all growth \& yield parameters e.g. total chlorophyll contents in leaves, dry matter production, flower appearance, length of fruits and fruits per plant, dry weight of 100 seeds, yield per plot and yield per hectare were signifi- 
cantly higher in those plots which received vermicompost either alone or in combination with chemicals. The highest fruit yield of 109 ton/ha was recorded in plots which received vermicompost @ 2.5 tons/ha [96].

In addition to increasing plant growth and productivity, vermicompost may also increase the nutritional quality of some vegetable crops such as tomatoes [97], Chinese cabbage [98], spinach [99], strawberries [56] and lettuce [100].

\section{TROUBLESHOOTING}

There are two major problems in the process of making vermin compost.

Death of worms in large and small numbers

- Worms are dying for the following reasons:

- If they are not getting enough food, therefore food should be buried into the bedding.

- Food may be too dry, so moisture should be maintained until it is slightly damp.

- Food may be too wet, in which case bedding should be added.

- The worms may be too hot, so the bin should be put in the shade.

\section{Bad smells from the vermicomposting grounds}

- It is due to that there is not enough air circulation. In this case, add dry bedding under and over the worms. Turning of the food may give better result.

- There may be present some materials such as meat, pet feces, or greasy foods, which are harmful in the compost, pit. These should be removed.

\section{Important practical points for vermiculture}

- No smell if the right products or bedding and feed are used.

- No need to turn the compost as the worms act like little ploughs turning the bedding and food.

- Air is circulating on a continuous period.

- Composting time is short in comparison to other composts.

- Composting can be done year round.

\section{HUNGRY WORMS \& FUTURE EARTHWORM BIOTECHNOLOGY}

Various approaches were employed in recent past to understand the mechanism of odorant and pheromone perception in diverse organisms. This has led to the identification of the pathways and a number of molecules involved in signal transduction. Intelligent use of behavioral genetic screens in C. elegans, close to earthworm in evolutionary scale has revealed a broader array of proteins that participate in chemosensation including pheromone perception. In mammals, odorants or pheromones bind to a seven trans-membrane G-protein coupled receptor. This results in the activation of adenyl cyclase via
G-protein homologs. cAMP production in turn activates $\mathrm{Ca}^{2+}$-permeant $\mathrm{CNG}$ channels that produces an electric signal recognized and processed by the worm brain. In $C$. elegans, there are increasing evidences that two distinct pathways of odor perception operates, one utilizing cAMP or cGMP and a CNG-like channel that is similar to the mammalian pathway, and a second mechanism that uses an unidentified second messenger and a capsasin like cation channel. Genetic screens for worms that are unable to chemotax to particular odor(s) have also allowed identification of peripheral players, such as ODR-4, that contribute to the transduction process. The discoveries arising from combining different experimental approaches in organisms where chemosensation plays fundamentally distinct roles are likely to provide insight into evolution and elaboration of sensory systems. Recently, in an exciting discovery Kawano et al., 2005 reported that a crude extract of worm relative C. elegans including dauer pheromone could enhance the lifespan of worms. The possible mechanism of action is through insulin pathway [101].

\section{CONCLUSIONS}

"Vermiculture Movement" is going on in India with multiple objectives of community waste management, highly economical way of crop production, which replaces the costly chemical fertilizers, and poverty eradication programs in villages. Vermicomposting to a nonprofessional simply means making of compost by worms by utilizing worm's innate behavior. Vermicomposting process improves soil aeration and thereby promotes the survival and dispersal of the useful bacterium within such systems, which is slowly becoming clear day by day. Vermicomposts could be prepared from the kitchen waste, farm waste, market waste, even from biodegradable city waste. The most effective uses of earthworms are organic waste management and supplement of readily available plant nutrients and vermicompost demands the credit as it maintains as well as improves soil health.

The chemical fertilizers are produced from "vanishing resources" of earth. Farmers urgently need a sustainable alternative, which is both economical and productive while also maintaining soil health \& fertility. The new concept is "Ecological Agriculture", which is by definition different from "Organic Farming" that was focused mainly on production of chemical free foods. Ecological agriculture emphasizes on total protection of food, farm \& human ecosystems while improving soil fertility \& development of secondary source of income for the farmers. UN has also endorsed it. Vermiculture provides the best answer for ecological agriculture, which is synonymous with "sustainable agriculture". Thereby it may be concluded that during the present time the most bene- 
ficiary from the scheme is our environment. This article opens the scope for further several researches.

\section{REFERENCES}

[1] US Board of Agriculture (1980) Report and recommendations on organic farming-Case studies of 69 organic farmers in USA. Publication of US Board of Agriculture.

[2] Gandhi, M., Sangwan, V., Kapoor, K.K. and Dilbaghi, N. (1997) Composting of household wastes with and without earthworms. Environment and Ecology, 15, 432-434.

[3] Vermi Co. (2001) Vermicomposting technology for waste management and agriculture: An executive summary. Vermi Co., Grants Pass. http://www.vermico.com/summary.htm

[4] Tara Crescent (2003) Vermicomposting. Development Alternatives (DA) sustainable livelihoods. http://www.dainet.org/livelihoods/default.htm

[5] Ruz-Jerez, B.E., Ball, P.R. and Tillman, R.W. (1992) Laboratory assessment of nutrient release from a pasture soil receiving grass or clover residues, in the presence or absence of Lumbricus rubellus or Eisenia fetida. Soil Biology and Biochemistry, 24, 1529-1534. doi:10.1016/0038-0717(92)90145-N

[6] Parkin, T.B. and Berry, E.C. (1994) Nitrogen transformations associated with earth worm casts. Soil Biology and Biochemistry, 26, 1233-1238. doi:10.1016/0038-0717(94)90148-1

[7] Reinecke, A., Viljoen, S.V. and Saayman, R. (1992) The suitability of Eudrilus eugenie, Perionyx excavatus and Eisenia fetida (Oligochaeta) for vermicomposting in southern Africa in terms of their temperature requirements. Soil Biology and Biochemistry, 24, 1295-1307 doi:10.1016/0038-0717(92)90109-B

[8] Ferreras, L., Gomez, E., Toresani, S., Firpo, I. and Rotondo, R. (2006). Effect of organic amendments on some physical, chemical and biological properties in a horticultural soil. Bioresource Technology, 97, 635-640. doi:10.1016/j.biortech.2005.03.018

[9] Marinari, S., Masciandaro, G., Ceccanti, B. and Grego, S. (2000). Influence of organic and mineral fertilizers on soil biological and physical properties. Bioresource Technology, 72, 9-17. doi:10.1016/S0960-8524(99)00094-2

[10] Gopinath, K.A., Supradip, S., Mina, B.L., Pande, H., Kundu, S. and Gupta, H.S. (2008) Influence of organic amendments on growth, yield and quality of wheat and on soil properties during transition to organic production. Nutrient Cycling in Agroecosystems, 82, 51-60. doi:10.1007/s10705-008-9168-0

[11] Williams, A.P., Roberts, P. and Avery, L.M. (2006) Earth worms as vectors of Escherichia coli O 157:H7 in soil and vermicomposts. FEMS Microbiology Ecology, 58, 54-64. doi:10.1111/j.1574-6941.2006.00142.x

[12] Nagavallemma, K.P., Wani, S.P., Stephane, L., Padmaja, V.V., Vineela, C., Babu Rao, M. and Sahrawat, K.L. (2004) Vermicomposting: Recycling wastes into valuable organic fertilizer. Global Theme on Agrecosystems Report No. 8. Patancheru 502 324, International Crops Re- search Institute for the Semi-Arid Tropics, Andhra, $20 \mathrm{p}$.

[13] Jadhav, A.D., Talashilkar, S.C. and Pawar, A.G. (1997) Influence of the conjunctive use of FYM, vermicompost and urea on growth and nutrient uptake in rice. Journal of Maharashtra Agricultural Universities, 22, 249-250.

[14] Ansari, A.A. (2008) Effect of Vermicompost on the Productivity of Potato (Solanum tuberosum) Spinach (Spinacia oleracea) and Turnip (Brassica campestris). World Journal of Agricultural Sciences, 4, 333-336.

[15] Chaoui, H.I., Zibilske, L.M. and Ohno, T. (2003) Effects of earthworms casts and compost on soil microbial activity and plant nutrient availability. Soil Biology and BioChemistry, 35, 295-302. doi:10.1016/S0038-0717(02)00279-1

[16] Julka, J.M. (1983) A new genus and species of earthworm (Octochaetidae:Oligochaeta) from South India. Geobioscience New Reports, 2, 48-50.

[17] Lavelle, P. (1983) Agastrodrilus omodeo (Vaillaud), a genus of carnivorous earthworm from the Ivory coast. In : Satchell, J.E., Ed., Earthworm Ecology from Darwin to Vermiculture, Chapman and Hall, New York and London, 1983, 425-429.

[18] Julka, J.M. (2001) Earthworm diversity and it's role in agroecosystem. VII National symposium on soil biology and ecology. Bangalore University of Agricultural Sciences, Bangalore, 13-17.

[19] Dash, M.C. and Senapati, B.K. (1980) Cocoons morphology, hatching and emergence pattern in tropical earthworms. Pedobiologia, 20, 317-324.

[20] Ismail, S.A. (1997) Vermicology: The biology of Earthworms. Orient Longman Limited, Chennai, 1997, 92.

[21] Gajalakshmi, S., Ramasamy, E.V. and Abbasi, S.A. (2001) Potential of two epigeic and two anecic earth worm species in vermicomposting of water hyacinth. Bioresource Technology, 76, 177-181. doi:10.1016/S0960-8524(00)00133-4

[22] Garg P., Gupta, A. and Satya, S. (2006) Vermicomposting of different types of waste using Eisenia foetida: A comparative study. Bioresource Technology, 97, 391-395. doi:10.1016/j.biortech.2005.03.009

[23] Garg, V.K., Yadav, Y.K. and Sheoran, A. (2006) Livestock excreta management through vermicomposting using an epigeic earth worm Eisenia foetida. The Environmentalist, 26, 269-276. doi:10.1007/s10669-006-8641-Z

[24] Manna, M.C., Singh, M., Kundu, S., Tripathi, A.K. and Takkar, P.N. (1997) Growth and reproduction of the vermicomposting earthworm Perionyx excavatus as influenced by food materials. Biology and Fertility of Soils, 24, 129-132. doi:10.1007/BF01420233

[25] Atiyeh, R.M., Subler, S., Edwards, C.A., Bachman, G., Metzger, J.D. and Shuster, W. (2000) Effects of Vermicomposts and Composts on Plant Growth in Horticultural Container Media and Soil. Pedobiologia, 44, 579-590. doi:10.1078/S0031-4056(04)70073-6

[26] Arancon, N.Q., Edwards, C.A. and Atiyeh, R. (2004) Effects of vermicomposts produced from food waste on the growth and yields of greenhouse peppers. Bioresource Technology, 93, 139-144. 
doi:10.1016/j.biortech.2003.10.015

[27] Arancon, N.Q., Edwards, C.A. and Bierman, P. (2004) Influnces of vermicomposts on field strawberries: Effects on growth and yields. Bioresource Technology, 93, 145153. doi:10.1016/j.biortech.2003.10.014

[28] Lee, J.J., Park, R.D. and Kim, Y.W. (2004) Effect of food waste compost on microbial population, soil enzyme activity and lettuce growth. Bioresource Technology, 93, 21-28. doi:10.1016/j.biortech.2003.10.009

[29] Deolalikar, A.V. and Mitra, A. (1997) Application of paper mill solid waste vermicompost as organic manure in Rohu (Labeo rohita Hamilton) culture-A comparative study with other commercial organic manure. In: Azariah, J., et al., Eds., Proc. Int. Bioethics Workshop: Biomanagement of Biogeoresources, University of Madras, Chennai.

[30] Applehof, M., Webster, K. and Buckerfield, J. (1996) Vermicomposting in Australia and New Zealand. BioCycle, 37, 63-66.

[31] Ghabbour, S.I. (1973) Earthworm in agriculture: A modern evaluation. Indian Review of Ecological and Biological Society, 111, 259-271.

[32] Bhat, J.V. and Khambata, P. (1996) Role of earthworms in agriculture. Indian Council of Agriculture Research, New Delhi, 22, 36.

[33] Capowiez, Y., Cadoux S., Bouchand P., Roger-Estrade, J., Richard G. and Boizard, H. (2009) Experimental evidence for the role of earthworms in compacted soil regeneration based on field observations and results from a semi-field experiment. Soil Biology \& Biochemistry, 41, 711-717. doi:10.1016/j.soilbio.2009.01.006

[34] Li, K.M. (2005) Vermiculture industry in circular economy. Worm Digest. http://www.wormdigest.org/con tent/view/135/2/

[35] Canellas. L.P., Olivares, F.L., Okorokova, A.L. and Facanha, R.A. (2002) Humic acids isolated from earthworm compost enhance root elongation, lateral root emergence, and plasma membrane $\mathrm{H}^{+}$- ATPase activity in maize roots. Journal of Plant Physiology, 130, 1951-1957.

[36] Li, K. and Li, P.Z. (2010) Earthworms helping economy, improving ecology and protecting health. In: Sinha, R.K. et al., Eds., Special Issue on "Vermiculture Technology", International Journal of Environmental Engineering, Inderscience Publishing, Olney.

[37] Nielson, R. (1965) Presence of plant growth substances in Earthworms demonstrated by Paper Chromatography and the Went Pea Test. Nature, 208, 1113-1114. doi: $10.1038 / 2081113 \mathrm{a} 0$

[38] Ayres, M. (2007) Suppression of soilborn plant disease using compost. 3rd National Compost Research and Development Forum Organized by COMPOST Australia, Murdoch University, Perth.

[39] Edwards, C.A. (1995) Historical overview of vermicomposting. Biocycle, 36, 56-58.

[40] Suhane, R.K. (2007) Vermicompost. Rajendra Agriculture University, Pusa, 88.

[41] Abbot, I. and Parker, C.A. (1981) Interactions between earthworms and their soil environments. Soil Biology and Biochemistry, 13, 191-197. doi:10.1016/0038-0717(81)90019-5

[42] Becker B. (1991) The benefits of earthworms. Natural Food and Farming, 12.

[43] Scheu, S. (1987) Microbial activity and nutrient dynamics in earthworms casts. Journal of Biological Fertility Soils, 5, 230-234.

[44] Edwards, C.A. and Burrows, I. (1988) The potential of earthworms composts as plant growth media. In: Edward, C.A. and Neuhauser, E.F., Eds., Earthworms in Waste and Environmental Management, SPB Academic Publishing, The Hague, 21-32.

[45] Tomati, U., Grappelli, A. and Galli, E. (1987) The presence of growth regulators in earthworm worked wastes. Proceeding of International Symposium on "Earthworms", Bologna-Carpi, 31 March-4 April 1985, 423-436.

[46] Tomati, V., Grappelli, A. and Galli, E. (1995) The Hormone like Effect of Earthworm Casts on Plant Growth. Biology and Fertility of Soils, 5, 288-294.

[47] Gaddie, R.E. and Douglas, D.E. (1975) Earthworms for ecology and profit. Scientific Earthworm Farming, Bookworm Publishing Company, 1, 175.

[48] Karmegam, N., Alagumalai, K. and Daniel, T. (1999) Effect of vermicompost on the growth and yield of green gram (Phaseolus aureus Roxb.). Tropical Agriculture, 76, 143-146.

[49] Atiyeh, R.M., Arancon, N.Q., Edwards, C.A. and Metzger, J.D. (2000) Influence of earthworm-processed pig manure on the growth and yield of green house tomatoes. Bioresource Technology, 75, 175-180. doi:10.1016/S0960-8524(00)00064-X

[50] Zaller, J.G. (2007) Vermicompost as a substitute for peat in potting media: Effects on germination, biomass allocation, yields and fruit quality of three tomato varieties. Scientia Horticulturae, 112, 191-199. doi:10.1016/j.scienta.2006.12.023

[51] Arancon, N.Q., Edwards, C.A., Babenko, A., Cannon, J., Galvis, P. and Metzger, J.D. (2008) Influences of vermicomposts, produced by earthworms and microorganisms from cattle manure, food waste and paper waste, on the germination, growth and flowering of petunias in the greenhouse, Applied Soil Ecology, 39, 91-99. doi:10.1016/j.apsoil.2007.11.010

[52] Lazcano, C., Sampedro, L., Zas, R. and Domínguez, J. (2010a) Vermicompost enhances germination of the maritime pine (Pinus pinaster Ait.). New Forest, 39, 387-400. doi:10.1007/s11056-009-9178-Z

[53] Edwards, C.A., Domínguez, J. and Arancon, N.Q. (2004) The influence of vermicomposts on plant growth and pest incidence. In: Shakir, S.H. and Mikhaill, W.Z.A., Eds., Soil Zoology for Sustainable Development in the 21st Century, Cairo, 397-420.

[54] Lazcano, C., Arnold, J., Tato, A., Zaller, J.G. and Domínguez, J. (2009). Compost and vermicompost as nursery pot components: Effects on tomato plant growth and morphology. Spanish Journal of Agricultural Research, 7, 944-951. 
[55] Atiyeh, R.M., Arancon, N., Edwards, C.A. and Metzger, J.D. (2002) The influence of earthworm-processed pig manure on the growth and productivity of marigolds. Bioresource Technology, 81, 103-108. doi:10.1016/S0960-8524(01)00122-5

[56] Singh, R., Sharma, R.R., Kumar, S., Gupta, R.K. and Patil, R.T. (2008) Vermicompost substitution influences growth, physiological disorders, fruit yield and quality of strawberry (Fragaria xananassa Duch). Bioresource Technology, 99, 8507-8511. doi:10.1016/j.biortech.2008.03.034

[57] Singh, R.D. (1992) Harnessing the earthworms for sustainable agriculture. Publication of Institute of National Organic Agriculture, Pune, 1-16.

[58] Arancon, N. (2004) An interview with Dr. Norman Arancon. Casting Call, 9.

[59] Anonymous (2001) Vermicompost as Insect Repellent. Biocycle.

[60] Edwards, C.A. and Arancon, N. (2004) Vermicompost suppresses plant pests and disease attacks. Rednova News.

[61] Munroe, G. (2007) Manual of on-farm vermicomposting and vermiculture. Organic Agriculture Centre of Canada, Nova Scotia.

[62] Biradar, A.P., Sunita, N.D., Teggelli, R.G. and Devaranavadgi, S.B. (1998) Effect of vermicomposts on the incidence of subabul psyllid. Insect Environment, 4, 5556.

[63] Ramesh, P. (2000) Effects of vermicomposts and vermincomposting on damage by sucking pests to ground nut (Arachis hypogea). Indian Journal of Agricultural Sciences, 70, 334.

[64] Rao, K.R. (2002) Induced host plant resistance in the management of sucking insect pests of groundnut. Annals of Plant Protection Science, 10, 45-50.

[65] Edwards, C.A., Arancon, N.Q., Emerson, E. and Pulliam, R. (2007) Suppressing plant parasitic nematodes and arthropod pests with vermicompost teas. BioCycle, 48, 3839.

[66] Arancon, N.Q., Edwards, C.A. and Lee, S. (2002) Management of plant parasitic nematode population by use of vermicomposts. Proceedings of Brighton Crop Protection Conference-Pests and Diseases, Brighton, 705-716.

[67] Noble, R. and Coventry, E. (2005) Suppression of soilborne plant diseases with composts: A review. Biocontrol Science and Technology, 15, 3-20. doi:10.1080/09583150400015904

[68] Termorshuizen, A.J., Van Rijn, E., Van der Gaag, D.J., Alabouvette, C., Chen, Y., Lagerlöf, J., Malandrakis, A.A., Paplomatas, E.J., Rämert, B., Ryckeboer, J., Steinberg, C. and Zmora-Nahum, S. (2006) Suppressiveness of 18 composts against 7 pathosystems: Variability in pathogen response. Soil Biology and Biochemistry, 38, 2461-2477. doi:10.1016/j.soilbio.2006.03.002

[69] Trillas M.I., Casanova, E., Cotxarrera, L., Ordovás, J., Borrero, C. and Avilés, M. (2006) Composts from agricultural waste and the Trichoderma asperellum strain T-34 suppress Rhizoctonia solani in cucumber seedlings.
Biological Control, 39, 32-38 doi:10.1016/j.biocontrol.2006.05.007

[70] Orlikowski, L.B. (1999) Vermicompost extract in the control of some soil borne pathogens. International Symposium on Crop Protection, 64, 405-410.

[71] Nakasone, A.K., Bettiol, W. and de Souza, R.M. (1999) The effect of water extracts of organic matter on plant pathogens. Summa Phytopathologica, 25, 330-335.

[72] Szczech, M. (1999) Supressiveness of vermicompost against Fusarium wilt of tomato. Journal of Phytopathology, 147, 155-161.

[73] Szczech, M., Smolinska, U. (2001) Comparison of suppressiveness of vermicompost produced from animal manures and sewage sludge against Phytophthora nicotianae Breda de Haar var. nicotianae. Journal of Phytopathology, 149, 77-82. doi:10.1046/j.1439-0434.2001.00586.x

[74] Edwards, C.A., Arancon, N.Q. and Greytak, S. (2006) Effects of vermicompost teas on plant growth and disease. BioCycle, 47, 28-31.

[75] Kale, R.D. (2006) The role of earthworms and research on vermiculture in India. In: Guerrero III, R.D., Guerrero-del Castillo, M.R.A., Eds., Vermi Technologies for Developing Countries. Proceedings of the International Symposium-Workshop on Vermi Technologies for Developing Countries, Los Baños, 16-18 November 2005, 6688.

[76] Guerrero, R.D. (2009) Vermicompost and vermimeal production. MARID Agribusiness Technology Guide, 22 p.

[77] Guerrero, R.D. (2009) Commercial vermimeal production: Is it feasible? In: Guerrero, R.D., Eds., Vermi Technologies for Developing Countries. Proceedings of the International Symposium-Workshop on Vermi Technologies for Developing Countrie, Los Baños, 16-18 November 2005, 112-120.

[78] Baker, G.H., Williams, P.M., Carter, P.J. and Long, N.R. (1997) Influence of lumbricid earthworms on yield and quality of wheat and clover in glasshouse trials. Journal of Soil Biology and Biochemistry, 29, 599-602. doi:10.1016/S0038-0717(96)00185-X

[79] Baker, G.H., Brown, G., Butt K., Curry, J.P. and Scullion, J. (2006) Introduced earthworms in agricultural and reclaimed land: Their ecology and influences on soil properties, plant production and other soil biota. Biological Invasions, 8, 1301-1316. doi:10.1007/s10530-006-9024-6

[80] Krishnamoorthy, R.V. and Vajranabhaiah, S.N. (1986) Biological activity of earthworm casts: An assessment of plant growth promoter levels in the casts. Proceedings of Indian Academy of Sciences (Animal Science), 95, 341351. doi:10.1007/BF03179368

[81] Palanisamy, S. (1996) Earthworm and plant interactions. ICAR Training Program, Tamil Nadu Agricultural University, Coimbatore.

[82] Roberts, P., Jones, G.E. and Jones, D.L. (2007) Yield responses of wheat (Triticum aestivum) to vermicompost. Journal of Compost Science and Utilization, 15, 6-15.

[83] Suthar, S. (2005) Effect of vermicompost and inorganic 
fertilizer on wheat (Triticum aestivum) production. Nature Environment Pollution Technology, 5, 197-201.

[84] Suthar, S. (2010) Vermicompost: An environmentally safe, economically viable and socially acceptable nutritive fertilizer for sustainable farming; In: Sinha, R.K., et al., Eds., Special Issue on Vermiculture Technology, Journal of Environmental Engineering, Inderscience Publishing, Olney.

[85] Kale, R.D., Mallesh, B.C., Kubra, B. and Bagyaraj, D.J. (1992) Influence of vermicompost application on the available macronutrients and selected microbial populations in a paddy field. Soil Biology and Biochemistry, 24, 1317-1320. doi:10.1016/0038-0717(92)90111-A

[86] Jeyabal, A. and Kuppuswamy, G. (2001) Recycling of organic wastes for the production of vermicompost and its response in rice legume cropping system and soil fertility. European Journal of Agronomy, 15, 153-170. doi:10.1016/S1161-0301(00)00100-3

[87] Guerrero, R.D. and Guerrero, L.A. (2008) Effect of vermicompost on the yield of upland rice in outdoor containers. Asia Life Sciences, 17, 145-149.

[88] Buckerfield, J.C. and Webster, K.A. (1998) Worm worked waste boost grape yield: Prospects for vermicompost use in vineyards. The Australian and New Zealand Wine Industry Journal, 13, 73-76.

[89] Sinha, R.K., Herat, S., Valani, D. and Chauhan, K. (2009) Vermiculture and sustainable agriculture. American-Eurasian Journal of Agricultural and Environmental Sciences, IDOSI Publication, 1-55.

[90] Webster, K.A. (2005) Vermicompost increases yield of cherries for three years after a single application. EcoResearch, South Australia.

[91] Atiyeh, R.M., Subler, S., Edwards, C.A. and Metzger, J.D. (1999) Growth of tomato plants in horticultural potting media amended with vermicompost. Pedobiologia, 43, $1-5$.

[92] Gupta, A.K., Pankaj, P.K. and Upadhyava, V. (2008) Effect of vermicompost, farm yard manure, biofertilizer and chemical fertilizers $(\mathrm{N}, \mathrm{P}, \mathrm{K})$ on growth, yield and quality of lady's finger (Abelmoschus esculentus). Pollution Research, 27, 65-68.

[93] Guerrero, R.D. and Guerrero, L.A. (2006) Response of eggplant (Solanum melongena) grown in plastic containers to vermicompost and chemical fertilizer. Asia Life Sciences, 15, 199-204.
[94] Agarwal, S, Sinha, R.K. and Sharma, J. (2010) Vermiculture for sustainable horticulture: Agronomic impact studies of earthworms, cow dung compost and vermicompost vis-à-vis chemical fertilizers on growth and yield of lady's finger (Abelmoschus esculentus). In: Sinha, R.K. et al., Eds., Special Issue on Vermiculture Technology, International Journal of Environmental Engineering, Inderscience Publishing, Olney.

[95] Meena, R.N., Singh, Y., Singh, S.P., Singh, J.P. and Singh, K. (2007) Effect of sources and level of organic manure on yield, quality and economics of garden pea (Pisum sativam L.) in eastern Uttar Pradesh. Vegetable Science, 34, 60-63.

[96] Karmegam, N. and Daniel, T. (2008) Effect of vermincompost and chemical fertilizer on growth and yield of Hyacinth Bean (Lablab purpureas). Dynamic Soil, Dynamic Plant, Global Science Books, 2, 77-81.

[97] Gutiérrez-Miceli, F.A., Santiago-Borraz, J., Montes Molina, J.A., Nafate, C.C., Abdud-Archila, M., Oliva Llaven, M.A., Rincón-Rosales, R. and Deendoven L. (2007) Vermicompost as a soil supplement to improve growth, yield and fruit quality of tomato (Lycopersicum esculentum). Bioresource Technology, 98, 2781-2786. doi:10.1016/j.biortech.2006.02.032

[98] Wang, D., Shi, Q., Wang, X., Wei, M., Hu, J., Liu, J. and Yang, F. (2010) Influence of cow manure vermicompost on the growth, metabolite contents, and antioxidant activities of Chinese cabbage (Brassica campestris ssp. chinensis). Biology and Fertility of Soils, 46, 689-696. doi:10.1007/s00374-010-0473-9

[99] Peyvast, G., Olfati, J.A., Madeni, S. and Forghani, A. (2008) Effect of vermicompost on the growth and yield of spinach (Spinacia oleracea L.). Journal of Food Agriculture and Environment, 6, 110-113.

[100] Coria-Cayupán, Y.S., De Pinto, M.I.S. and Nazareno, M. A. (2009) Variations in bioactive substance contents and crop yields of lettuce (Lactuca sativa L.) cultivated in soils with different fertilization treatments. Journal of Agricultural and Food Chemistry, 57, 10122-10129. doi:10.1021/jf903019d

[101] Kawano, T., Kataoka, N. and Abe, S. (2005) Lifespan extending activity of substances secreted by the nematode Caenorhabditis elegans that include the dauer-inducing pheromone. Bioscience, Biotechnology and Biochem, 69, 2479-2481. doi:10.1271/bbb.69.2479 